\title{
Allopolyploid speciation and ongoing backcrossing between diploid progenitor and tetraploid progeny lineages in the Achillea millefolium species complex: analyses of single-copy nuclear genes and genomic AFLP
}

\author{
Jin-Xiu Ma1, ${ }^{1}$, Yan-Nan Li², Claus Vogl33 , Friedrich Ehrendorfer ${ }^{4}$ and Yan-Ping Guo*1
}

\begin{abstract}
Background: In the flowering plants, many polyploid species complexes display evolutionary radiation. This could be facilitated by gene flow between otherwise separate evolutionary lineages in contact zones. Achillea collina is a widespread tetraploid species within the Achillea millefolium polyploid complex (Asteraceae-Anthemideae). It is morphologically intermediate between the relic diploids, A. setacea-2x in xeric and A. asplenifolia-2x in humid habitats, and often grows in close contact with either of them. By analyzing DNA sequences of two single-copy nuclear genes and the genomic AFLP data, we assess the allopolyploid origin of A. collina- $4 \mathrm{x}$ from ancestors corresponding to $A$. setacea- $2 x$ and $A$. asplenifolia-2x, and the ongoing backcross introgression between these diploid progenitor and tetraploid progeny lineages.

Results: In both the ncpGS and the PgiC gene tree, haplotype sequences of the diploid A. setacea-2x and A. asplenifolia$2 x$ group into two clades corresponding to the two species, though lineage sorting seems incomplete for the PgiC gene. In contrast, A. collina-4x and its suspected backcross plants show homeologous gene copies: sequences from the same tetraploid individual plant are placed in both diploid clades. Semi-congruent splits of an AFLP Neighbor Net link not only A. collina- $4 x$ to both diploid species, but some $4 x$ individuals in a polymorphic population with mixed ploidy levels to A. setacea-2x on one hand and to A. collina-4x on the other, indicating allopolyploid speciation as well as hybridization across ploidal levels.

Conclusions: The findings of this study clearly demonstrate the hybrid origin of Achillea collina-4x, the ongoing backcrossing between the diploid progenitor and their tetraploid progeny lineages. Such repeated hybridizations are likely the cause of the great genetic and phenotypic variation and ecological differentiation of the polyploid taxa in Achillea millefolium agg.
\end{abstract}

\section{Background}

According to the genealogical species concept, species are defined as multi-locus "genotypic clusters" that remain distinct even in the presence of gene flow among each other [1-3]. "Hybridization is thus a normal feature of species biology" [1]. Hybridization and its results, e.g.,

* Correspondence: guoyanping@bnu.edu.cn

${ }^{1}$ Ministry of Education Key Laboratory for Biodiversity Science and Ecological Engineering, and College of Life Sciences, Beijing Normal University, Beijing 100875, China

Full list of author information is available at the end of the article introgression, segregation of new types without backcrossing, and allopolyploidy, have long been speculated as major forces behind "evolutionary bursts" [4]. Indeed, plant species and populations arisen from hybridization and polyploidy often exhibit more complicated patterns of variation than their progenitors, i.e., their diploid sister groups, and are ecologically divergent, presumably under local selection. Furthermore, when gene flow is present between the diverged progenies or between the parental and daughter lineages, the genetic and phenotypic com- 
plexity of the populations could be enhanced. All these processes may increase species diversity and obliterate discrete separation lines between otherwise diverged taxa as observed in many angiosperm polyploid complexes [49].

Achillea millefolium agg. (Asteraceae-Anthemideae) is a highly polymorphic but clearly monophyletic polyploid species complex or aggregate. It is composed of outbreeding hemicryptophytic perennials widely distributed over the N Hemisphere. Five to seven diploid and 10-30 polyploid taxa can be defined in this complex [10,11]. Autopolyploidy has been documented in the $\mathrm{N}$ American populations, which serve as textbook examples for plant ecotypic differentiation [12,13]. Most of the Eurasian polyploids, ranging from tetra- to octoploids, are either derived from primary hybridization between diploid progenitors or may be products of secondary introgression on the same or on different ploidy levels. This has created complex genetic and phenotypic variation patterns within A. millefolium agg. [14-18]. The relationships of the diploid species conform to a tree structure, whereas most of the polyploid taxa exhibit complex and reticulate relationships with each other and with the diploid species $[11,19]$.

Achillea collina is a widely distributed tetraploid member of $A$. millefolium agg. in Europe. It is morphologically intermediate between the relic diploids, $A$. setacea-2x in xeric and $A$. asplenifolia-2x in humid habitats, and often grows in close contact with either of them [14]. Cytogenetic analyses and crossing experiments of $A$. asplenifolia and $A$. setacea have resulted in $\mathrm{F}_{1}$ and $\mathrm{F}_{2}$ generations with reduced vitality and fertility. Thus, the two diploid species are separated by considerable intrinsic barriers. From their diploid $\mathrm{F}_{2}$ hybrid progeny, several spontaneous allotetraploid individuals could be obtained. They were morphologically quite similar to the wild species $A$. collina$4 \mathrm{x}$, fertile, and could be crossed with the latter [14]. Previous AFLP analyses have suggested $A$. setacea-2x and $A$. asplenifolia-2x as the most likely progenitors of $A$. collina-4x [19]. In the Austrian province of Burgenland, south of Vienna, we found several natural hybrid swarms where either morphologically "typical" $A$ setacea-2x or "typical" A. asplenifolia-2x come into contact with $A$. collina-4x. We suspect some $4 \mathrm{x}$ plants in these hybrid zones to be products of backcrosses from A. setacea-2x or $A$. asplenifolia- $2 \mathrm{x}$ via unreduced egg cells to their assumed daughter species $A$. collina-4x. Clarification of genetic relationships of these diploid and tetraploid individuals and populations should improve our understanding of the enormous species diversity and the complex patterns of variation in $A$. millefolium agg.

To resolve reticulate relationships and recent radiation, single- or low-copy nuclear genes are preferable because $i$ ) they can provide co-dominant molecular markers for identifying hybridization and/or introgressive events, $i$ ) they often provide multiple unlinked loci with fast evolving introns, and are thus more informative than the plastid DNA, iii) such low-copy nuclear loci are less susceptible than ribosomal genes to gene conversion, which can reduce or eliminate allelic heterozygosity. The major problem in utilizing low-copy nuclear genes is to distinguish orthologs from paralogs. Only with orthologs, phylogenetic interpretations make sense [20-22]. In addition, PCR-recombination can also be a problem when sequencing nuclear genes, especially from polyploid genomes. When two partially homologous templates exist in one PCR reaction, an in vitro chimera could be formed from the non-identical templates. This can happen when amplifying members of multigene families or any locus from polyploid genomes [23,24]. By optimizing PCR conditions, the frequency of PCR recombination can be reduced [24]. Nevertheless, data should be interpreted cautiously to avoid biased evolutionary interpretations due to artificially recombinant molecules [23].

With large numbers of markers, the AFLP method can help to obtain genome-wide perspectives about populations under processes influencing the entire genome, such as gene flow and genetic drift. Therefore, this is a powerful tool in recognizing hybridization events $[19,25,26]$.

Here we use sequences of two single-copy nuclear genes, the chloroplast-expressed glutamine synthase gene (ncpGS) and the cytosolic phosphoglucose isomerase gene $(P g i C)$ as well as AFLP data to demonstrate allopolyploid speciation and ongoing hybrid introgression by backcrossing between diploid progenitor and tetraploid progeny lineages in Achillea millefolium agg..

\section{Results}

\section{Genealogical relationships based on the nuclear gene sequences}

Amplifications for both the ncpGS and the PgiC locus yielded a single band from each individual sample. The ncpGS haplotype sequences of the $2 \mathrm{x}$ individuals and populations group into two clades corresponding to the two diploid species (Fig. 1a), thus clearly belong to a set of single-copy orthologs. The PgiC gene tree does not completely correspond to the divergence of the diploid species (Fig. 2a). This can be attributed to incomplete sorting of two ancestral PgiC alleles in Achillea millefolium agg. (Fig. 2c) or to introgression (for detailed interpretation, see the "Discussion"). Therefore, all the PgiC sequences studied here also belong to one orthologous gene lineage.

The original complete ncpGS data matrix contains 327 sequences (clones) from 60 individuals of 14 studied populations and the outgroup A. ligustica. The final ncpGS gene tree (Fig. 1b) was built on 80 consensus sequences ranging in length from 873 to 921 bps. The alignment 


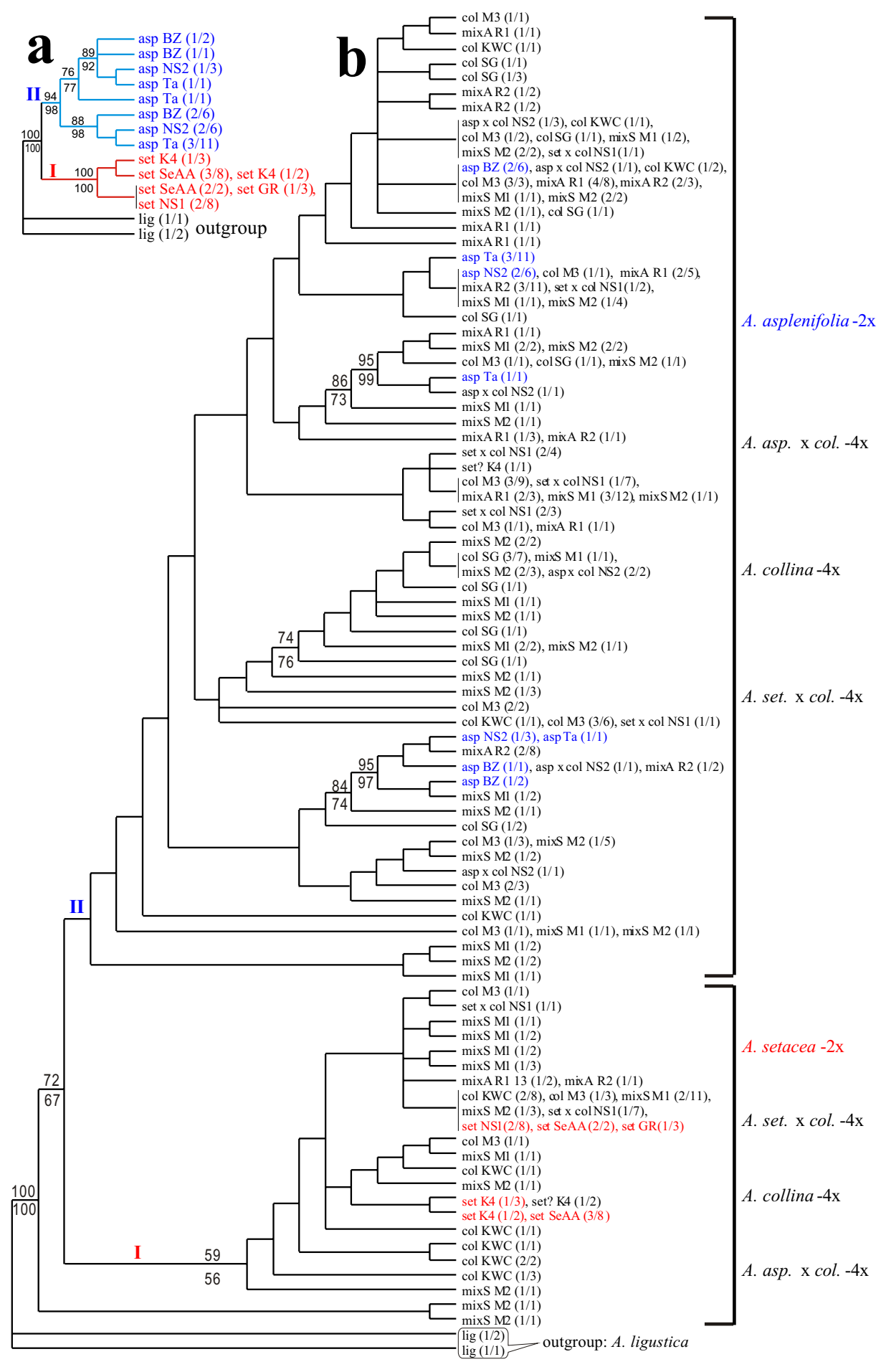

Figure 1 Maximum parsimonious ( $50 \%$ majority-rule consensus) trees of the ncp GS gene. a. For the diploid species Achillea setacea and A. asplenifolia only based on 13 consensus sequences and two equally most parsimonious trees (tree length $=119, \mathrm{Cl}=0.8824, \mathrm{Rl}=0.9343$ ). $\mathbf{b}$. For all the studied diploid and tetraploid species and populations based on 80 consensus sequences and 8700 equally most parsimonious trees (tree length $=$ $403, \mathrm{Cl}=0.4491, \mathrm{Rl}=0.8649$ ). Bootstrap supports (>50\%) from MP/NJ analyse are shown above/below the major branches. Label for the sequence (terminal node) is written as "taxa abbreviation \# population code (number of individuals/number of clones)". Abbreviations: asp $=A$. asplenifolia-2x, set $=$ A. setacea- $2 x, c o l=A$. collina- $4 x$, mixA $=$ mixed populations of $A$. asplenifolia- $2 x$ and suspected $A$. asplenifolia $x$ collina- $4 x$ backcross individuals, mixS $=$ mixed populations of $A$. setacea- $2 x$ and suspected $A$. setacea $\times$ collina- $4 x$ backcross individuals. 


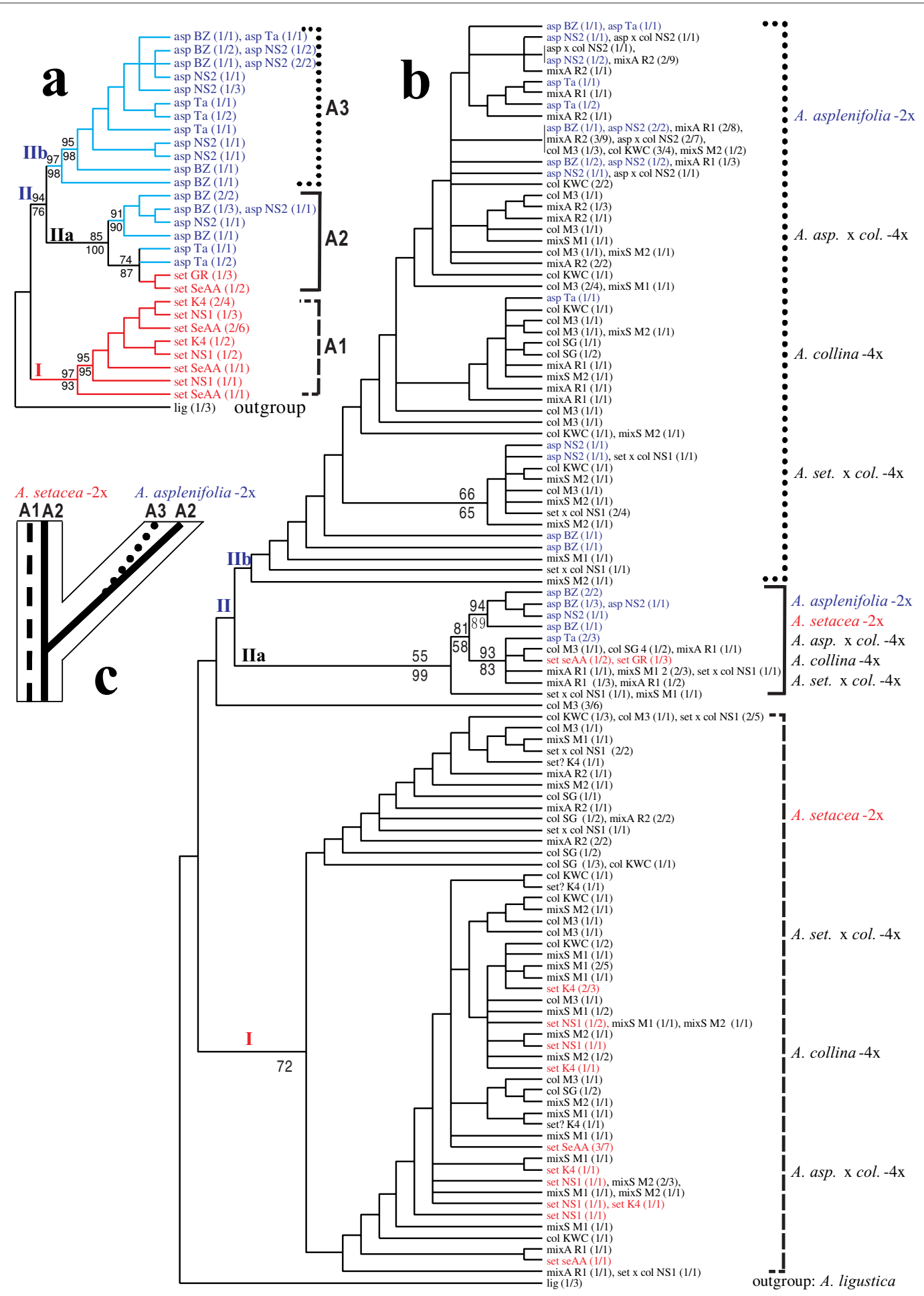

Figure 2 Maximum parsimonious (50\% majority-rule consensus) trees of the PgiC gene. a. For the diploid species Achillea setacea and A. asplenifolia only based on 29 consensus sequences and 14 equally most parsimonious trees (tree length $=212, \mathrm{Cl}=0.6415, \mathrm{Rl}=0.9007$ ). $\mathbf{b}$. For all the studied diploid and tetraploid species and populations based on 109 consensus sequences and 7840 equally most parsimonious trees (tree length $=508, \mathrm{Cl}$ $=0.3484, \mathrm{Rl}=0.8909$ ). Bootstrap supports ( $>50 \%)$ from MP/NJ analyse are shown above/below the major branches. Label for the sequence (terminal node) is written as "taxa abbreviation \# population code (number of individuals/number of clones)". Abbreviations: asp $=A$. asplenifolia-2x, set $=A$. setacea-2x, col = A. collina-4x, mixA = mixed populations of $A$. asplenifolia- $2 \mathrm{x}$ and suspected $A$. asplenifolia $\times$ collina-4x backcross individuals, mixS $=$ mixed populations of $A$. setacea- $2 x$ and suspected $A$. setacea $\times$ collina- $4 x$ backcross individuals. c. Proposed scheme of incomplete lineage sorting of the PgiC gene. Species are outlined by thin solid lines; alleles A1, A2 and A3 are represented by dashed, thick solid, and dotted lines, respectively. 
contains 971 nucleotide positions, of which 869 (195 in exon and 666 in intron regions) were included in the phylogenetic analysis containing 151 parsimony-informative characters.

The original complete PgiC data set contains 252 sequences (clones) from the same 59 out of 60 individuals analyzed for the ncpGS locus. The final PgiC gene tree (Fig. 2b) was built on 109 consensus sequences ranging in length from 1619 to 1674 bps. The alignment contains 1720 nucleotide positions, of which 1579 (646 in exon and 933 in intron regions) were included in the phylogenetic analysis containing 127 parsimony-informative characters.

A heuristic search retained 8700 equally most parsimonious $(\mathrm{MP})$ trees (tree length $=403, \mathrm{CI}=0.4491, \mathrm{RI}=$ 0.8649 ) from the 80 consensus ncpGS sequences and $7840 \mathrm{MP}$ trees (tree length $=508, \mathrm{CI}=0.3484$, $\mathrm{RI}=$ 0.8909 ) from the 109 consensus PgiC sequences. Topologies of the MP and NJ trees were broadly similar. Figs. 1 and 2 show the $50 \%$ majority rule consensus MP trees. Internal node supports (Bootstrap Percentages) from both MP and NJ methods were presented on the trees.

Phylogenetic analyses were first conducted for the diploid species only (Figs. 1a \&2a). Rooted by the Central Mediterranean Achillea ligustica-2x, each of the gene trees contains two well supported clades: clade I corresponds to A. setacea-2x in both gene trees, and clade II in the ncpGS tree to $A$. asplenifolia-2x only, whereas in the PgiC tree, subclade IIa (haplotype group A2) contains sequences not only of $A$. asplenifolia-2x, but also a few of A. setacea-2x (populations SeAA and GS from Anatolia and Greece). We interpret the haplotype group A2 orthologous to A1 and A3, and designate A1 and A2 as polymorphic alleles of the PgiC gene from the ancestral lineage of $A$. millefolium agg. (more in the "Discussion" part).

In contrast to the diploid individuals and populations, the tetraploid A. collina and its suspected backcross hybrids in the polymorphic "mixed" populations show homeologous copies at both ncpGS and PgiC loci. In most cases, different sequences from the same tetraploid individual plant were placed in different diploid clades (Figs. 1b \&2b; Additional files 1 and 2: Figs. S1 \& S2).

\section{AFLP split network}

Three primer pairs generated a total of 273 clear and unambiguous AFLP bands from 93 individuals of eight populations. Out of the 273 bands, 245 (89.7\%) were polymorphic. The $4 \mathrm{x}$-accessions have more bands (average 127.1 bands per individual) than the $2 x$ ones (average 115.6 bands per individual in A. asplenifolia-2x and 114.2 in $A$. setacea-2x). Thirty-seven differences of 4386 phenotypic comparisons were observed based on the 17 replicated individuals, thus the error rate is $0.84 \%$. Fig. 3 shows a Neighbor Net of the 93 individuals studied by the AFLP method. Two major splits, highlighted by red and blue, correspond to A. setacea-2x and A. asplenifolia-2x, respectively. The box formed by the semi-congruent blue and green splits indicates the hybrid status of $A$. collina$4 \mathrm{x}$. The incompatible yellow and purple splits link the $A$. setacea $\times$ collina $-4 \mathrm{x}$ individuals from population NS1 to A. setacea on the one hand and to A. collina on the other, demonstrating backcross introgression between the latter two.

\section{Discussion}

Achillea setacea and A. asplenifolia are two diploid species of the monophyletic $A$. millefolium agg. [11,19]. They represent two extremes of morphological and ecological differentiation within this species aggregate, the former hairy, small, and adapted to xeric steppe environments, the latter tall, glabrous, and adapted to undisturbed wet environments. Achillea setacea-2x is sporadically distributed from NE Anatolia and SE Europe to the Balkans, Hungary, Slovakia, Moravia, Austria and interior valleys of the Alps, and in the north to S Poland, E Germany and the N Czech Rep; whereas, A. asplenifolia-2x occurs locally from Bulgaria and Hungary to E Austria and the southern Czech Republic [10,11,27]. In the ncpGS gene tree, haplotype sequences of $A$. setacea-2x and $A$. asplenifolia-2x group well into two clades corresponding to the two species (Fig. 1a), the PgiC gene tree, however, does not completely correspond to the divergence of the diploid species (the subclade IIa of Fig. 2a inclues both $A$. asplenifolia-2x and $A$. setacea-2x) (Fig. 2a). Our data clearly show that both the ncpGS and PgiC genes are single-copy in Achillea millefolium agg.. To explain the partial incongruence of the PgiC gene tree with the divergence of the diploid species (Fig. 2a), two interpretations can be put forward: $i$ ) incomplete sorting of ancestrally polymorphic alleles, or $i i$ ) of introgression during secondary contact of the two diploid species. Considering the current allelic distribution, the former interpretation is more likely as shown below.

Assuming incomplete lineage sorting (Fig. 2c) [28], allele A2 might have been retained from an ancestor of $A$. millefolium agg. in some populations of the extant $A$. setacea (the Greek and Anatolia populations, GR and SeAA) and in $A$. asplenifolia, but was apparently lost during the migration of $A$. setacea to the north and the west, e.g., in the Ukrainean and Austrian populations (K4 and NS1). Allele A3, which appears in A. asplenifolia, could have arisen from A2 after the divergence of this species in the Pannonian area, where it has survived locally in lowland areas in Hungary, Bulgaria, Austria, and Moravia (Figs. 2a \&2c).

Alternatively, one could also assume subclade IIa of Fig. 2a (A2) to be the result of hybrid introgression from $A$. 


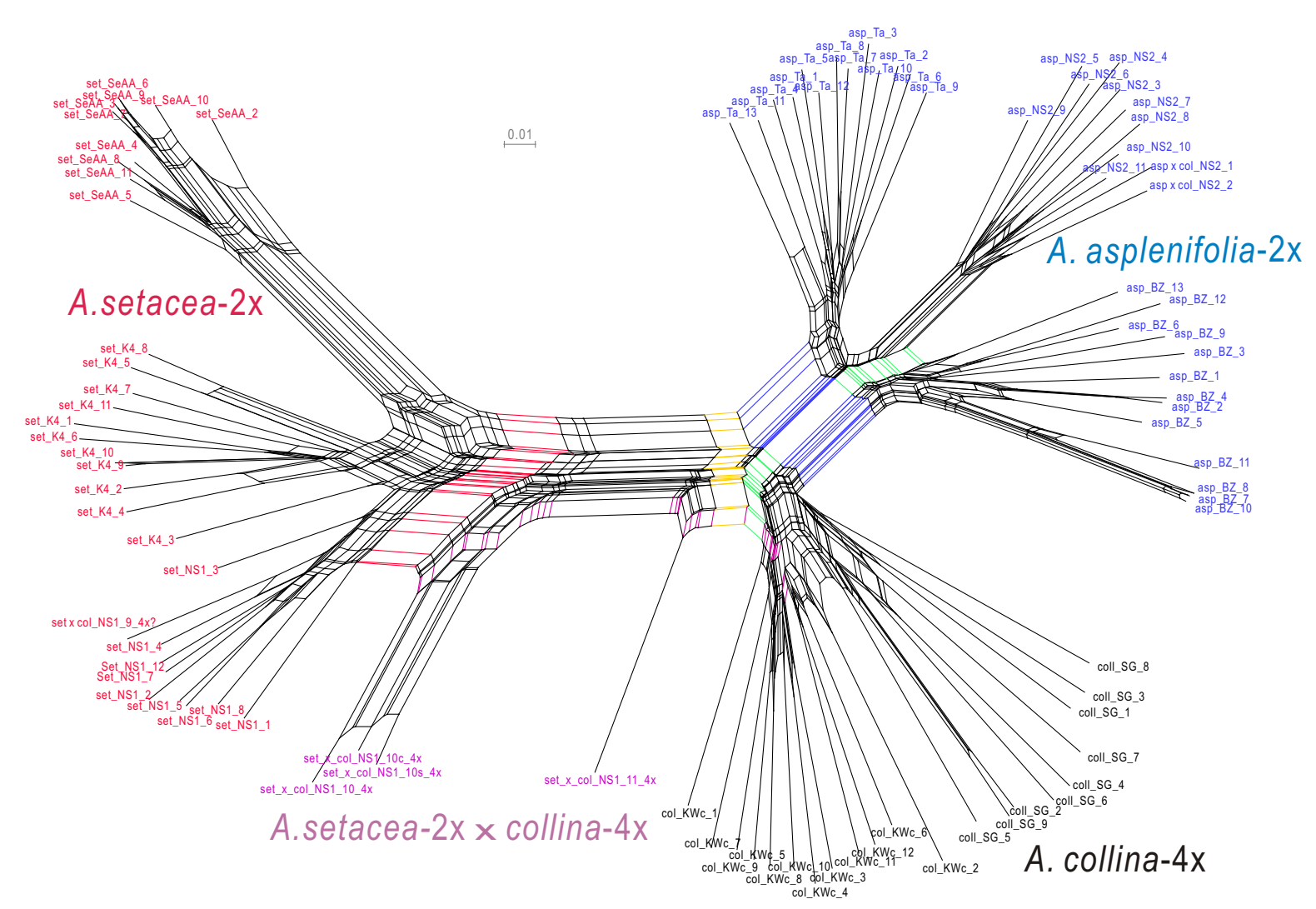

Figure 3 Neighbor Net derived from 273 AFLP bands of 93 individuals from eight populations of the two diploid progenitor lineages Achillea setacea-2x and $A$. asplenifolia-2x, the allotetraploid $A$. collina- $\mathbf{4} \mathbf{x}$ and backcross individuals. Node labels include taxa abbreviations (asp $=$ A. asplenifolia- $2 x$, set $=A$. setacea- $2 x, \mathrm{col}=A$. collina- $4 x$ ) and population codes.

asplenifolia-2x into A. setacea-2x. This is unlikely considering the current geographic distribution of the two diploid species and the occurrence of allele A2 among populations of $A$. setacea-2x (only in its south-eastern populations, SeAA and GR, that grow outside the distribution area of $A$. asplenifolia-2x). However, the refugia of the two species may have been in closer proximity in SE Europe during the ice-ages, and they may have hybridized there. If so, allele A2 must have been lost from A. setacea$2 \mathrm{x}$ during its northward migration. But this scenario is again unlikely because there are no signs of hybrid introgression between $A$. asplenifolia-2x and A. setacea-2x throughout the Pannonian area, where they often occur in close proximity. A clear separation of the two diploid species is also strongly suggested by the ncp $G S$ gene tree (Fig. 1a). Thus, we assume that two PgiC alleles A1 and A2 existed already in the ancestral lineage and may have been sorted incompletely after the divergence of $A$. asplenifolia and $A$. setacea, while allele A3 has arisen within A. asplenifolia after its species separation (Fig. 2c).
In contrast to the clear genetic and morphological separation of Achillea setacea-2x and A. asplenifolia-2x, $A$. collina-4x is morphologically intermediate between these two diploid species and also linked by intermediates to other 4x-taxa of $A$. millefolium agg.. Unlike the two relic diploid species, $A$. collina-4x has widely expanded in various mesic and open vegetation types from $S E$ and $E$ to $C$ Europe and is much more aggressive in disturbed habitats. From experimental crosses between $A$. asplenifolia$2 \mathrm{x}$ and $A$. setacea-2x, synthetic allotetraploid and $A$. collina-like plants were produced and successfully backcrossed to natural $A$. collina-4x [14]. These early results were supported by AFLP analyses which showed that species-specific bands of the two diploids are combined in A. collina-4x [19].

The present sequence data from single-copy nuclear genes ncp GS and PgiC (Figs. 1, 2) demonstrate that all the haplotype sequences of the diploid individuals or populations are grouped corresponding to the two species, Achillea setacea-2x and $A$. asplenifolia-2x respectively. In contrast, sequences of nearly all populations and many 
individuals of $A$. collina-4x (and its suspected 4x-hybrids) are placed among both the diploid Achillea setacea and $A$. asplenifolia clades. Therefore, homeologs of the nuclear single-copy genes in A. collina-4x demonstrate its allotetraploid origin. Additional evidence for this conclusion comes from the AFLP Neighbor Net (Fig. 3). That many of the A. collina-4x individuals (in the PgiC gene tree, most individuals) harbor homoeologous gene copies (Additional file 1 \&2: Figs. S1 \& S2) suggests at least partly disomic inheritance of this tetraploid species. Its diploid progenitors must have been closely related to the extant $A$. setacea-2x and $A$. asplenifolia-2x, and probably have differentiated in SE Europe. Their hybridization and the origin of an allotetraploid progeny may have taken place in the Pannonian region, where their distribution areas still overlap.

With the establishment of $A$. collina-4x, a first cycle of hybridization and differentiation was completed. But was the further expansion of this young allotetraploid species accompanied by complete isolation from or by continued backcrossing with its diploid progenitor lineages? Earlier experiments of crossing 2x- and 4x-taxa of the A. millefolium agg. never have produced $3 \mathrm{x}$-hybrids but can occasionally gave rise to $4 \mathrm{x}$-progeny via unreduced egg cells from the $2 x$ side [14]. Such unreduced gametes occur frequently in A. millefolium agg. [29]. In Burgenland, Austria, populations of $A$. setacea-2x, A. asplenifolia-2x and A. collina-4x grow in two areas about $4 \mathrm{~km}$ apart: southeast of Rust and St. Margarethen (see Additional file 3, Table S1 for population sampling information). Ongoing gene flow may exist among their populations: Polymorphic populations M1 and M2 with mixed ploidal levels of $2 \mathrm{x}$ and $4 \mathrm{x}$ were found in disturbed grassland surrounding the morphologically more typical $A$. setacea-2x population NS1 on natural steppe islands near St. Margarethen, whilst NS1 itself also contains a few phenotypically intermediate $4 x$-plants. Similarly, at the outer border zone of lake Neusiedlersee near Rust, in contact zones between $A$. asplenifolia-2x in natural humid meadows and $A$. collina-4x from adjacent disturbed grassland, $4 \mathrm{x}$-plants with intermediate phenotype were found in populations $\mathrm{R} 1$, R2 and NS2 (see Additional file 3, Table S1 for population sampling information). Our study, especially the AFLP network (Fig. 3), suggests these 4x-plants result from backcrosses of the $2 \mathrm{x}$-taxa to $A$. collina- $4 \mathrm{x}$ via unreduced female gametes. The possibility of reverse gene flow from $4 \mathrm{x}$ to $2 \mathrm{x}$ will need a further critical study.

There are several other examples for ongoing hybridization between taxa on different ploidy levels in Achillea: A contact zone between $A$. asplenifolia-2x and A. collina$4 \mathrm{x}$, comparable to the one in Austria, was studied in $\mathrm{W}$ Hungary [30]. A. virescens is an allo-4x-species, which has arisen from hybridization between $A$. collina-4x and A. nobilis-2x. Its backcrossing with $A$. collina-4x has been demonstrated in NE Italy [18]. The yellow flowering SEEuropean $A$. clypeolata-2x has formed an extensive 4xhybrid swarm with $A$. collina-4x in Bulgaria [19,31]. In addition, natural and experimental crosses between $A$. collina-4x and $A$. millefolium-6x are quite successful; via semifertile $5 \mathrm{x}-\mathrm{F}_{1}$, aneuploid- $\mathrm{F}_{2}$ and backcrosses they rapidly produce normal euploid $4 \mathrm{x}$ or $6 \mathrm{x}$ progeny and support gene flow between the two ploidy levels [32].

\section{Conclusions}

Combining all molecular and cytogenetic data [[11$14,19,29]$, etc.], we conclude that most of the polyploid taxa in Achillea millefolium agg. are allopolyploids or at least more or less strongly influenced by hybridization. Polyploid taxa often occur in close contact with each other and with diploids. This not only makes hybridization between polyploid taxa at the same ploidy level omnipresent, but facilitates introgression between taxa on different ploidy levels. Introgression of genetic material into diploid taxa, either from other diploid taxa or from polyploids, however, seems rare. Hybrid swarms common in natural zones of contacts between different taxa lead to the great genetic and ecological differentiation and variation of the polyploid taxa in the A. millefolium species complex.

\section{Methods \\ Plant materials}

For the present study, 14 populations of A. millefolium agg. were sampled (see Additional file 3, Table S1 for sampling information on taxa and populations): three of Achillea asplenifolia-2x (BZ, Ta, NS2, where NS2 contains a few individuals probably being $A$. asplenifolia $\mathrm{x}$ collina), three of $A$. collina-4x (SG, KWC, M3), four of $A$. setacea-2x (SeAA, GR, K4, NS1, where NS1 contains a few tetraploid individuals defined as A. setacea x collina), and four polymorphic "mixed" populations (R1, R2, M1, M2, where "pure" $2 \mathrm{x}$-taxa occur together with suspected hybrids, forming an array of interspecific recombinations). For the AFLP analysis, the highly polymorphic populations (R1, R2, M1, M2, M3) were left out due to band complications in a trial experiment. Also excluded from the AFLP genotyping was the single-individual accession of $A$. setacea from Greece (GR). For rooting the gene trees, the uniform $\mathrm{C}$-Mediterranean species $A$. ligustica-2x was used as outgroup. This is a basal species in $A$. sect. Achillea and sister to A. millefolium agg. [19,33].

Chromosome counts and DNA ploidy level determinations were conducted for the populations and individuals in this study (see Additional file 3, Table S1 for ploidy level information on each population). Young flower buds were used for chromosome counting following standard methods and DNA ploidal levels were investigated by 
means of propidium iodide flow cytometry [34,35] from silica gel dried leaves.

\section{DNA extraction}

Total genomic DNA was extracted from ca. $0.02 \mathrm{~g}$ silica gel desiccated leaf materials following the $2 x$ CTAB protocol [36] with slight modifications: Before the normal extraction process, sorbitol washing buffer was used to remove polysaccharides in the leaf materials (add $800 \mu \mathrm{L}$ sorbitol buffer to the ground leaf powder $\mathrm{T}$ incubate the sample in ice for $10 \mathrm{~min}$. T centrifuge at 10,000 g for 10 min at $4^{\circ} \mathrm{C}$ T add $700 \mu \mathrm{L}$ warm $2 x$ CTAB extraction buffer and then follow the established $2 \mathrm{x}$ CTAB protocol).

\section{PCR, cloning and sequencing of the single-copy nuclear genes}

We sequenced two single-copy loci, the chloroplastexpressed glutamine synthase gene (ncpGS) and the cytosolic phosphoglucose isomerase gene $(\mathrm{PgiC})$, both having a clear molecular evolutionary background and studied in other eudicots [37-45].

The ncpGS gene contains 12 exons and 11 introns [37]. The region from exon 7 to 11 was amplified and sequenced. Exon-primed amplifications were performed using specific primers GS-f and GS-r designed for Achillea (Table 1), or in some cases, amplification was first conducted with a universal primer pair GScp687f and GScp994r [40] followed by nested PCR with the Achilleaspecific primers.

The PgiC gene contains 23 exons and 22 introns [41]. The region from exon 11 to 21 was amplified and sequenced. Exon-primed amplifications were performed using Achillea-specific primers PgiC-11F and PgiC-21R (Table 1), or in a few cases, first with universal primers AA11F and yamv [45] and then by nested PCR using the Achillea-specific primers.

The amplification reaction was carried out in a volume of $20 \mu \mathrm{L}$ containing $2 \mu \mathrm{L} \mathrm{10x}$ PCR buffer, $0.5 \mathrm{U}$ exTaq
(TaKaRa, Shiga, Japan) or HiFi (TransTaq DNA polymerase High Fidelity, TransGen Biotech), $200 \mu \mathrm{M}$ of each dNTP, $0.2 \mu \mathrm{L}$ DMSO, $0.5 \mu \mathrm{M}$ of each primer, $1 \mu \mathrm{L}$ template DNA, and $\mathrm{ddH}_{2} \mathrm{O}$ added to the final volume. The amplification was conducted on a Peltier thermocycler (Bio-RAD) with the following cycling scheme: $5 \mathrm{~min}$ at $94^{\circ} \mathrm{C}$; 30 cycles of $1 \mathrm{~min}$ at $94^{\circ} \mathrm{C}, 30 \mathrm{~s}$ at $50^{\circ} \mathrm{C}$, and $1.5 \mathrm{~min}$ at $72^{\circ} \mathrm{C}$; a $15 \mathrm{~min}$ extension at $72^{\circ} \mathrm{C}$; and a final hold at $4^{\circ} \mathrm{C}$. The PCR products were electrophoresed on and excised from $1.0 \%$ agarose gel in TAE buffer. They were then purified using DNA Purification kit (TianGen Biotech or TransGen Biotech, Beijing, China). The purified PCR products were ligated into pGEM-T vector with a Promega Kit (Promega Corporation, Madison, USA). About 3-5 clones from each diploid and 5-15 from each tetraploid individual with the right insertion were randomly selected for sequencing. The plasmid was extracted with an Axyprep Kit (Axygene Biotechnology, Hangzhou, China). Cycle sequencing was conducted using ABI PRISM ${ }^{\circ}$ BigDye $^{\text {Ta }}$ Terminator and vector primers T7/Sp6. In the case of PgiC gene, a third Achillea-specific internal primer PgiC-14F (Table 1) was used to sequence the entire $\sim 1.7 \mathrm{~kb}$-fragment. The sequenced products were run on an ABI PRISM $^{\mathrm{TM}} 3700$ DNA Sequencer (PE Applied Biosystems).

\section{AFLP genome scan}

AFLP profiles were generated following established procedures [46] and PE Applied Biosystems [47]. Total genomic DNA was digested with $M s e$ and EcoRI. Preselective amplifications were performed using primer pairs with single nucleotides, MseI-C and EcoRI-A, and selective amplifications using three primer combinations, MseI-CAG/EcoRI-ACT (FAM), MseI-CTT/EcoRI-ACC (NED) and MseI-CAG/EcoRI-AGG (HEX). The fluorescence-labeled selective amplification products were run in a $4.5 \%$ denaturing polyacrylamide gel with the ABI Prism 377 Sequencer. Repeated restriction, amplification,

Table 1: Primers used for amplification and sequencing

\begin{tabular}{lll}
\hline Primer name & Primer sequence & Reference or source \\
\hline GScp687f & 5'-GATGCTCACTA CAAGGCTTG-3' & {$[40]$} \\
GScp994r & 5'-AATGTG CTCTTTGGGCGAAG-3' & {$[40]$} \\
GS-f & 5'-AACCAATGGAGAAGTATGC-3' & this study \\
GS-r & 5'-CAAAACCACCTTCTCTCTC-3' & this study \\
AA11F & 5'-TTY GCN TTY TGG GAY TGG GT-3 & {$[45]$} \\
Yamv (reverse) & 5'-TCI ACI CCC CAI TGR TCA AAI GAR TII AT-3' & {$[45]$} \\
PgiC-11F & 5'-TY TGGGAYTGGGTAGGAG-3' & this study \\
PgiC-14F & 5'-GAGTGTATGGAATGTCTC-3' & this study \\
PgiC-21R & 5'-GGARTTGATCCCCAAAC-3' & this study \\
\hline
\end{tabular}


and run of bands of a subset of samples (2-3 individuals per population) indicated reliability of the present AFLP data. In total, 17 individuals were used for error rate estimation [48]. Bands were scored with Genographer (version 1.6, ${ }^{\circ}$ Montana State University, 1998; http:// hordeum.oscs.montana.edu/genographer/) in a size range from $50 \sim 500 \mathrm{bp}$. To avoid ambiguities, only bands with sufficient florescent intensity were scored and used as markers for analyses.

\section{Data analyses}

Sequences were assembled with the ContigExpress program (Informax Inc. 2000, North Bethesda, MD), aligned with ClustalX 1.81, and then manually improved with BioEdit version 7.0.1. Singletons were identified via DnaSP ver. 4.10.9 [49]; they mostly could be due to PCR artefacts rather than reflect natural variability [50] and were not included in the data analyses. Majority-rule consensus sequences for clones [51] were constructed following a two-step strategy: First, the original data matrix was imported to the software DAMBE (Data Analysis in Molecular Biology and Evolution) [52] so that multiple sequences belonging to the same haplotype were combined into one, and the thus retained data set was used for an initial phylogenetic analyses; second, following the initial phylogenetic analysis, the number of sequences was further reduced by eliminating some suspected PCR-recombinant sequences (see Additional file 4) and by combining several polytomic haplotypes into one. Such retained data set of consensus sequences was used for the final phylogenetic analyses. These consensus sequences are labeled by the population codes and the number (amount) of individuals and clones (Figs. 1 \&2). Those used as consensus sequences were deposited in the NCBI GenBank under accession numbers FJ434254FJ434336.

Phylogenetic analyses were performed separately on the PgiC and the ncpGS data sets with PAUP* version 4.0b10a using both Maximum Parsimony (MP) and Neighbor Joining (NJ) methods. All nucleotide substitutions were equally weighted. Gaps were treated as missing data. For the MP method, heuristic searches were performed using 1000 random taxon addition replicates with ACCTRAN optimization and TBR branch swapping. Up to 10 trees with scores larger than 10 were saved per replicate. The stability of internal nodes of the MP tree was assessed by bootstrapping with 1000 replicates (MulTrees option in effect, TBR branch swapping and simple sequence addition). The NJ analysis was conducted with Kimura's 2-parameter distances [53] and bootstrapped with 1000 replicates.

Earlier reconstruction of the phylogeny of Achillea millefolium agg. using AFLP data showed that only the relationships of the diploid taxa conform to a bifurcating tree. Inclusion of the polyploid taxa, however, destabilizes the tree to such an extent that the distinctness of related groups becomes blurred $[11,19]$. Phylogenetic networks should be preferred over phylogenetic trees when reticulate events are to be expected as is the case here [54]. Therefore, the present AFLP data were analyzed using the Neighbor-Net method [55] with uncorrected p-distances embedded in SplitsTree4. In the network, parallel edges represent splits of taxa/populations, while nodes that connect incompatible splits often represent taxa/ populations with hybrid origin (though conflicting signals could also be caused by homoplasy or methodological artifacts) [54].

\section{Additional material}

Additional file 1 Fig. S1 The $50 \%$ majority-rule consensus MP tree corresponding to Fig. $1 \mathrm{~b}$ with original labels of the terminal nodes. In Fig. S1, we provide original labels for terminal nodes which are simplified in Fig. 1 .

Additional file 2 Fig. S2 The $50 \%$ majority-rule consensus MP tree corresponding to Fig. $2 \mathrm{~b}$ with original labels of the terminal nodes. In Fig. S2, we provide original labels for terminal nodes which are simplified in Fig. 2.

Additional file 3 Table S1 Taxa and populations studied. In Table S1, we provide the sampling information on taxa and populations, e.g., their names, geographic localities and habitats, ploidy levels as well as number of individuals and cloned sequences analyzed by this study.

Additional file $4 \mathrm{~A}$ list of sequences obtained by this study and those deleted for the final data analyses. In this list, we highlight the

sequences deleted during our final data analyses. These sequences might contain PCR artefacts, e.g., PCR-mediated recombination which is inevitable when sequencing nuclear genes from genomes where two partially homologous templates exist. We further briefly discuss the methods to avoid such artefact in experiments and to identify PCR-recombinant sequences in data analysis.

\section{Authors' contributions}

JXM and YNL performed the lab work, participated in the data analysis and helped to draft the manuscript. CV participated in the design of the study, collected part of the plant samples and provided input on manuscript drafting. YPG and FE conceived the project and collected most of the plant samples. FE identified all plant materials and provided significant input on manuscript drafting, whereas YPG conducted the final statistical analysis and drafted the manuscript. All authors read and approved the final manuscript.

\section{Acknowledgements}

We thank the National Natural Science Foundation of China (Grant No. 30570107 and 30770144 to Y.-P. Guo) and the Austrian Science Foundation (FWF, project P16148-B03 to F. Ehrendorfer) for financial support, and the College of Life Sciences, Beijing Normal University for the facilities provided. We are grateful to E. Temsch, J Li and M. Lambrou for providing technical instructions on DNA ploidy level determinations and chromosome counts, and to L. Ehrendorfer-Schratt for collecting some of the samples. Particular thanks are due to J. Saukel and J. Ramsey (Rochester, N.Y.) for important additional informations on their Achillea research and valuable discussions, and to two anonymous referees for improving the manuscript.

\section{Author Details}

'Ministry of Education Key Laboratory for Biodiversity Science and Ecological Engineering, and College of Life Sciences, Beijing Normal University, Beijing 100875, China, ${ }^{2}$ College of Biological Sciences and Biotechnology, Beijing Forestry University, Beijing, China, 3Institute of Animal Breeding and Genetics, University of Veterinary Medicine in Vienna, A-1210 Vienna, Austria, ${ }^{4}$ Department of Systematic and Evolutionary Botany, Faculty of Life Sciences, University of Vienna, A-1030 Vienna, Rennweg 14, Austria and ${ }^{5}$ Beijing Engineering Research Center for Hybrid Wheat, Beijing 100097, China 
Received: 27 April 2009 Accepted: 13 April 2010

Published: 13 April 2010

\section{References}

1. Mallet J: Hybrid speciation. Nature 2007, 446:279-283.

2. Morjan $\mathrm{CL}$, Rieseberg LH: How species evolve collectively: implications of gene flow and selection for the spread of advantageous alleles. $\mathrm{Mol}$ Ecol 2004, 13:1341-1356.

3. Wu C-1: The genic view of the process of speciation. J Evol Biol 2001, 14:851-865.

4. Anderson E, Stebbins GL: Hybridization as an evolutionary stimulus. Evolution 1954, 8:378-388.

5. Grant V: Plant Speciation New York, Columbia University Press; 1981.

6. Arnold ML: Natural Hybridization and Evolution Oxford, U.K., Oxford University Press; 1997.

7. Arnold ML: Transfer and origin of adaptations through natural hybridization: Were Anderson and Stebbins right? The Plant Cell 2004, 16:562-570

8. Soltis DE, Soltis PS, Tate JA: Advances in the study of polyploidy since Plant speciation. New Phytol 2003, 161:173-191.

9. Slotte T, Huang H, Lascoux M, Ceplitis A: Polyploid speciation did not confer instant reproductive isolation in Capsella (Brassicaceae). Mol Biol Evol 2008, 25:1472-1481

10. Ehrendorfer F, Guo Y-P: Multidisciplinary studies on Achillea sensu lato (Compositae-Anthemideae): New data on systematics and phylogeography. Willdenowia 2006, 36:69-87.

11. Guo Y-P, Saukel J, Ehrendorfer F: AFLP trees versus scatter plots: evolution and phylogeography of the polyploid complex Achillea millefolium agg. (Asteraceae). Taxon 2008, 57:1-17.

12. Clausen J, Keck D, Hiesey WM: Experimental studies on the nature of species. III. Environmental responses of climatic races of Achillea. Carnegie Inst Wash Publ 1948:581.

13. Ramsey J, Robertson A, Husband B: Rapid adaptive divergence in the New World Achillea, an autopolyploid complex of ecological races. Evolution 2008, 62:639-653.

14. Ehrendorfer F: Differentiation-Hybridization cycles and polyploidy in Achillea. Cold Spring Harbor Symposia on Quantitative Biology 1959, 24:141-152.

15. Ehrendorfer F: New chromosome numbers and remarks on the Achillea millefolium polyploid complex in North America. Österreichische Botanische Zeitschrift 1973, 122:133-143.

16. Vetter S, Lambrou M, Franz CH, Ehrendorfer F: Cytogenetics of experimental hybrids within the Achillea millefolium complex (yarrow). Caryologia 1996, 49:1-12.

17. Vetter S, Lambrou M, Franz CH, Ehrendorfer F, Saukel J: Chromosome numbers of experimental tetraploid hybrids and selfpollinated progenies within the Achillea millefolium complex (Compositae). Caryologia 1996, 49:227-231.

18. Rauchensteiner F, Nejati S, Werner I, GlasI S, Saukel J, Jurenitisch J, Kubelka W: Determination of taxa of the Achillea millefolium group and Achillea crithmifolia by morphological and phytochemical methods I.

Characterisation of Central European taxa. Scientia Pharmaceutica 2002, 70:199-230.

19. Guo Y-P, Saukel J, Mittermayr R, Ehrendorfer F: AFLP analyses demonstrate genetic divergence, hybridization, and multiple polyploidization in the evolution of Achillea (AsteraceaeAnthemideae). New Phytol 2005, 166:273-290.

20. Sang T: Utility of low-copy nuclear gene sequences in plant phylogenetics. Crit Rev Biochem MolBiol 2002, 37:121-147.

21. Small RL, Cronn RC, Wendel JF: Use of nuclear genes for phylogeny reconstruction in plants. Aust Syst Bot 2004, 17:145-170.

22. Wu F-N, Mueller LA, Crouzillat D, Pétiard V, Tanksley SD: Combining bioinformatics and phylogenetics to identify large sets of single-copy orthologous genes (COSII) for comparative, evolutionary and systematic studies: a test case in the Euasterid plant clade. Genetics 2006, 174:1407-1420.

23. Cronn R, Cedroni M, Haselkorn T, Grover C, Wendel JF: PCR-mediated recombination in amplification products derived from polyploid cotton. Theor App/ Genet 2002, 104:482-489.

24. Wu L, Tang T, Zhou R-C, Shi S-H: PCR-mediated recombination of the amplification products of the Hibiscus tiliaceus cytosolic glyceraldehyde-3-phosphate dehydrogenase gene. J Biochem Mole Biol 2007, 40:172-179.

25. Guo Y-P, Vogl C, Van Loo M, Ehrendorfer F: Hybrid origin and differentiation of two tetraploid Achillea species in East Asia: molecular, morphological and ecogeographical evidence. Mol Ecol 2006 15:133-144

26. Meudt HM, Clarke AC: Almost forgotten or latest practice? AFLP applications, analyses and advances. Trends Plant Sci 2007, 12:106-117.

27. Meusel H, Jäger EJ, Weinert E: Vergleichende Chorologie der zentraleuropäischen Flora, III Jena, G. Fischer Verlag; 1991

28. Nei M: Molecular Evolutionary Genetics New York, Columbia Univ. Press; 1987.

29. Ramsey J: Unreduced gametes and neopolyploids in natural populations of Achillea borealis (Asteraceae). Heredity 2007, 98:143-151.

30. Rauchensteiner F: Biodiversität südosteuropäischer Schafgarben - Analyse von Wildaufsamm/ngen Dissertation, MathematischNaturwissenschaftliche Fakultät der Universität Wien; 2002.

31. Saukel J, Anchev M, Guo Y-P, Vitkova A, Nedelcheva A, Goranova V, Konakchiev A, Lambrou M, Nejati S, Rauchensteiner F, Ehrendorfer F: Comments on the biosystematics of Achillea (AsteraceaeAnthemideae) in Bulgaria. Phytol Balcan ("2003") 2004, 9:361-400.

32. Schneider I: Zytogenetische Untersuchungen an Sippen des PolyploidKomplexes Achillea millefolium L. s. lat. (Zur Phylogenie der Gattung Achillea, I). Österreichische Botanische Zeitschrift 1958, 105:111-158.

33. Guo Y-P, Ehrendorfer F, Samuel R: Phylogeny and systematics of Achillea (Asteraceae-Anthemideae) inferred from nrlTS and plastid trnL-F DNA sequences. Taxon 2004, 53:657-672.

34. Temsch EM, Greilhuber J: Genome size variation in Arachis hypogaea and A. monticola re-evaluated. Genome 2000, 43:449-451.

35. Suda J, Krahulcova A, Travnicek P, Krahulec F: Ploidy level versus DNA ploidy level: an appeal for consistent terminology. Taxon 2006, 55:447-450

36. Doyle JJ, Doyle JL: A rapid DNA isolation procedure for small quantities of fresh leaf tissue. Phytochem Bull 1987, 19:11-15.

37. Tischer E, DasSarma S, Goodman HM: Nucleotide sequence of an alfalfa Medicago sativa glutamine synthetase gene. Mol Gen Genet 1986 203:221-229.

38. Doyle JJ: Evolution of higher plant glutamine synthetase genes: tissue specificity as a criterion for predicting orthology. Mol Biol Evol 1991, 8:366-377.

39. Biesiadka J, Legocki AB: Evolution of the glutamine synthetase gene in plants. Plant Science 1997, 28:51-58

40. Emshwiller E, Doyle JJ: Chloroplast-expressed glutamine synthetase (ncpGS): potential utility for phylogenetic studies with an example from Oxalis (Oxalidaceae). Mol Phylogenet Evol 1999, 12:310-319.

41. Thomas BR, Laudencia-Chingcuanco D, Gottlieb LD: Molecular analysis of the plant gene encoding cytosolic phosphoglucose isomerase. $\mathrm{Pl}$ Mol Biol 1992, 19:745-757.

42. Thomas BR, Ford VS, Pichersky E, Gottlieb LD: Molecular characterization of duplicate cytosolic phosphoglucose isomerase genes in Clarkia and comparison to the single gene in Arabidopsis. Genetics 1993, 135:895-905.

43. Ford VS, Gottlieb LD: Reassessment of phylogenetic relationships in Clarkia sect. Sympherica. Am J Bot 2006, 90:284-292.

44. Liu A-Z, Burke JM: Patterns of nucleotide diversity in wild and cultivated sunflower. Genetics 2006, 173:321-330.

45. Ford VS, Lee J, Baldwin BG, Gottlieb LD: Species divergence and relationships in Stephanomeria (Compositae): PgiC phylogeny compared to prior biosystematic studies. Am J Bot 2006, 93:480-490

46. Vos P, Hogers R, Bleeker M, Reijans M, Lee T van de, Hornes M, Fritjers A, Pot J, Peleman J, Kuiper M, Zabeau M: AFLP: a new technique for DNA fingerprinting. Nucl Acids Res 1995, 23:4407-4414.

47. PE Applied Biosystems: AFLPTM Plant Mapping Protocol Foster City, CA, PE Applied Biosystems; 1996.

48. Bonin A, Bellemain E, Bronken Eidesen P, Pompanon F, Brochmann C, Taberlet $P$ : How to track and assess genotyping errors in population genetics studies. Mol Ecol 2004, 13:3261-3273.

49. Rozas J, Sanchez-DelBarrio JC, Messeguer X, Rozas R: DnaSP, DNA polymorphism analyses by the coalescent and other methods. Bioinformatics 2003, 19:2496-2497. 
50. Zhang L-B, Ge S: Multilocus analysis of nucleotide variation and speciation in variation and speciation in Oryza officinalis and its close relatives. Mol Biol Evol 2007, 24:769-783.

51. Brysting AK, Oxelman B, Huber KT, Moulton V, Brochmann C: Untangling complex histories of genome mergings in high polyploids. Syst Biol 2007, 56:467-476.

52. Xia X, Xie Z: DAMBE: Data analysis in molecular biology and evolution. $J$ Hered 2001, 92:371-373.

53. Kimura $\mathrm{M}$ : A simple method for estimating evolutionary rates of base substitutions through comparative studies of nucleotide sequences. J Mol Evol 1980, 16:111-134

54. Huson DH, Bryant D: Application of phylogenetic networks in evolutionary studies. Mol Biol Evol 2006, 23:254-267. (Software available from http://www.splitstree.org/)

55. Bryant D, Moulton V: Neighbor-Net: an agglomerative method for the construction of phylogenetic networks. Mol Biol Evol 2004, 21:255-265.

doi: $10.1186 / 1471-2148-10-100$

Cite this article as: Ma et al., Allopolyploid speciation and ongoing back-

crossing between diploid progenitor and tetraploid progeny lineages in the Achillea millefolium species complex: analyses of single-copy nuclear genes and genomic AFLP BMC Evolutionary Biology 2010, 10:100

Submit your next manuscript to BioMed Central and take full advantage of:

- Convenient online submission

- Thorough peer review

- No space constraints or color figure charges

- Immediate publication on acceptance

- Inclusion in PubMed, CAS, Scopus and Google Scholar

- Research which is freely available for redistribution

Submit your manuscript at www.biomedcentral.com/submit
Ciomed Central 